\title{
A (RE)CONSTRUÇÃO DE MASCULINIDADES NA SESSÃO
}

\section{DE GRUPO SOCIOEDUCATIVO}

\section{LA (RE) CONSTRUCCIÓN DE LA MASCULINIDAD EN LA SESIÓN DEL GRUPO SOCIOEDUCATIVO}

\author{
THE (RE)CONSTRUCTION OF MASCULINITY AT THE SOCIO-EDUCATIONAL \\ GROUP SESSION
}

\begin{abstract}
RESUMO: O presente artigo discute a relação entre a participação em sessões de grupo socioeducativo (como um gênero discursivo) e a (re)construção de masculinidades de homens autores de violência contra a mulher. Para tanto, agencia o arcabouço teórico da Análise Crítica de Gêneros e analisa 12 sessões do referido grupo, em termos de horizonte temático, estrutura estilísticocomposicional e funcionamento. Trata-se de uma pesquisa de cunho etnográfico, desenvolvida ao longo de 12 meses numa cidade da região sul do Brasil. Os resultados apontam para disputas acerca dos significados da violência e a (des)naturalização desta última como aspecto constituinte de masculinidades.
\end{abstract}

PALAVRAS-CHAVE: Gênero discursivo. Masculinidades. Violência contra a mulher.

RESUMEN: Este artículo discute la relación entre la participación en sesiones de grupo socio educativo (como un género discursivo) y la (re)construcción de masculinidades, de hombres autores de violencia contra la mujer. Con este fin, se establece el marco teórico del Análisis Crítico de Géneros y se analiza 12 sesiones de dicho grupo, en términos de horizonte temático, estructura estilística y compositiva y funcionamiento. Esta es una investigación etnográfica, desarrollada durante 12 meses en una ciudad del sur de Brasil. Los resultados apuntan una disputa sobre los significados de la violencia y su (des)naturalización como un aspecto constitutivo de las masculinidades, un proceso que ocurre a través de una disputa sobre los casos de constitución del género discursivo.

*Docente da Universidade Estadual de Mato Grosso do Sul (UEMS). Integra o Núcleo de Estudos Bakhtinianos (NEBA) e o Grupo de pesquisa Educação, Cultura e Diversidade. Doutora em Linguística Aplicada (UFSC/NELA). E-mail: vanessa.arlesia@gmail.com. 
PALABRAS CLAVE: Género discursivo. Masculinidades. Violencia contra la mujer.

ABSTRACT: In this work, we take, as theoretical presuppositions, the notion-concept of discursive formation, as proposed by Michel Pêcheux (1997) and based on the article "Palavra de amor" (Word of Love), by Eni Orlandi (1990) to analyze, from the point of view of the French Discourse Analysis, fragments of songs in English and Portuguese languages. The analysis of the songs allowed us to perceive the discursive formations of love as pain or suffering and of love as nostalgia as constitutive formations of texts, revealed by enunciative regularities in operation through linguistic elements and characteristics of the texts. Due to the impossibility of dealing here with all the aspects investigated from the discourse of love, we reiterate the certainty that the notion-concept of discursive formation, as theorized by Pêcheux (1997), is still very productive. Likewise, we reaffirm the productivity of Orlandi's article (1990), despite its almost thirty years of meaning production.

KEYWORDS: Discoursive genre. Masculinity. Violence against women.

\section{INTRODUÇ̃̃O}

A masculinidade é uma dimensão das autoidentidades que integra centralmente as narrativas de si, constituindo modelos a partir dos quais homens e mulheres se narram. Ela se configura nas dinâmicas entre estrutura, prática e eventos sociais, sendo ela mesma compreendida, em sua versão hegemônica, como uma determinada configuração de práticas em termos de relações de gênero social (gender).

As práticas sociais, de maneira geral, têm sido focalizadas nas análises discursivas críticas, pois intermedeiam o que é sempre novo (evento) e o que é mais estável (estrutura). Relacionados à dimensão das práticas estão os gêneros discursivos (genres), que as realizam via tipificações semióticas orientadoras de formas de significar e agir, integrando habitus ${ }^{1}$. Como a vida é uma entidade aberta, o tensionamento de qualquer um desses aspectos traz também a possibilidade de novas configurações, um dos propósitos centrais da Análise Crítica de Gêneros (ACG).

Considerando tais pressupostos, a pesquisa aqui reportada ${ }^{2}$ tem por objetivo analisar como o gênero sessão de grupo socioeducativo para homens autores de violência contra a mulher se relaciona com a (re)configuração discursiva de masculinidades. Para tanto, discuto nas seções seguintes as relações entre autoidentidade, práticas sociais e gêneros discursivos; apresento o percurso metodológico da pesquisa reportada e, por fim, explicito a análise de 12 sessões do referido grupo em termos de: i) horizonte temático, ii) estrutura estilístico-composisional e iii) modo de funcionamento.

\section{AS PRÁTICAS SOCIAIS COMO LUGAR DA CONSTITUIÇÃO DE SI}

A autoidentidade - tomada aqui como sendo o contínuo processo de constituição de si - pode ser entendia "não [como] um traço distintivo, ou mesmo uma pluralidade de traços, possuído pelo indivíduo", mas como sendo o "eu compreendido reflexivamente pela pessoa em termos de sua biografia” (GIDDENS, 2002, p. 54). Tal processo de compreensão, por sua vez, só é possível por meio da linguagem (VOLOCHINOV, 2014). Isso ocorre porque a "[...] compreensão não pode manifestar-se senão através de um material semiótico [...]”. Aliás, “[...] a própria consciência só pode surgir e se afirmar como realidade mediante a encarnação material dos signos [...] a compreensão é uma resposta a um signo por meio de signos" (VOLOCHINOV, 2014, p. 33-4). Nesse sentido, a linguagem, então, assume um papel primordial na constituição das autoidentidades.

\footnotetext{
${ }^{1}$ Habitus está sendo entendido aqui como “[...] sistemas de disposições [relativamente] duráveis, estruturas estruturadas predispostas a funcionar como estruturas estruturantes, isto é, como um princípio gerador e estruturador das práticas e das representações que podem ser objetivamente 'reguladas' ou 'regulares' sem ser o produto da obediência a regras [...]" (BOURDIEU, 1994, p. 60-1)

${ }^{2}$ Pesquisa aprovada pelo Comitê de Ética em Pesquisa da UFSC, sob o Parecer n. 1.599.474.
} 
Além disso, a linguagem não é só material da consciência, é também material concreto da comunicação e só existe saturada por todo o contexto que integra as interações sociais. Nas palavras de Volochinov (2014, p. 45), “[...] as formas do signo são condicionadas tanto pela organização social de tais indivíduos como pelas condições em que a interação acontece”. Em outros termos, "[...] a palavra não comporta nada que não esteja ligado a essa função [de signo], nada que não tenha sido gerado por ela. A palavra é o modo mais puro e sensível da relação social" (VOLOCHINOV, 2014, p. 36). Portanto, aspectos da vida social passam a constituir as autoidentidades via reflexão e refração da linguagem.

Na esteira dessa discussão, as relações sociais (constituídas pela linguagem), por sua vez, não se dão num vácuo sócio-histórico, mas em contextos marcados por um cronotopo específico (RODRIGUES, 2004), no interior das práticas sociais. Aliás, para Fairclough (2003), as relações sociais são um dos aspectos constituidores das práticas, ao lado da própria linguagem (ou Discurso, como o autor nomeia) e das atividades materiais, por exemplo. Todas essas dimensões são sobredetermindas/significadas pela linguagem e agem, portanto, recursivamente na constituição de práticas e autoidentidades.

De maneira geral, as discussões de Giddens (1991, 1993, 2002) acerca das transformações da intimidade a partir das mudanças sóciohistóricas da modernidade tardia ilustram o modo como estruturas sociais constituem as práticas (lócus do encontro entre os aspectos potenciais e empíricos da existência) e, consequentemente, as autoidentidades (ou o modo como autoidentidades se constituem a partir das práticas).

Conforme aponta o autor (GIDDENS, 1991, 2002), transformações na ordem pós-tradicional - como o surgimento dos Estadosnação, o industrialismo, as mudanças nas relações de espaço-tempo, a introdução de sistemas abstratos entre outros desencadearam mudanças nas relações da intimidade e na própria constituição do eu, de modo que a reflexividade torna-se um dos elementos cada vez mais central desse contexto, relacionado não só com mudanças estruturais, mas principalmente com as mudanças na autoidentidade. Giddens explica que “[...] a contínua incorporação reflexiva do conhecimento não apenas se introduz na brecha, ela proporciona precisamente um ímpeto básico às mudanças que ocorrem nos contextos pessoais, e também globais, da ação" (GIDDENS, 1993, p. 39).

Na modernidade tardia, esse conhecimento é incorporado a partir de sistemas abstratos, isto é, sistemas de conhecimentos que "[...] penetram na vida cotidiana [e] normalmente oferecem múltiplas possibilidades em vez de fornecerem guias e receitas fixas de ação" (GIDDENS, 2002, p. 82). Assim, questões como "quem sou eu?", "qual o sentido de minha existência nesse mundo?", "como devo conduzir minha vida?" têm emergido como efeitos estruturados em habitus (BOURDIEU, 1994) e aspectos estruturantes das/nas práticas sociais, culminando em transformações das autoidentidades a partir de uma multiplicidade de práticas das quais os sujeitos participam, sendo estas cada vez mais marcadas por transformações amplas, intensificando a relação global-local e gerando, segundo Giddens (2002), medo, insegurança e contínua necessidade de escolhas diante de inúmeros estilos de vida ${ }^{3}$.

Em termos de masculinidades e feminilidades, essa problemática está presente, por exemplo, nos questionamentos de Betty Friedman sobre aquilo que ela rotulou de "[...] problema que não possui nome", ou seja, no modo como determinadas formas de compreensão de si (ou de papéis sociais, para usar termos da época) são postas em questão a partir da reflexividade (GIDDENS, 1993).

Na modernidade tardia, essas questões de natureza ontológica têm de ser respondidas não apenas cotidianamente, mas pressupõem uma ininterrupta interpretação de si, "[...] no desdobrar temporal da autoidentidade” (GIDDENS, 2002, p. 20). Nesse sentido, a identidade "[...] não é algo simplesmente apresentado, como resultado das continuidades do sistema de ação, mas algo que deve ser criado e sustentado rotineiramente nas atividades reflexivas do indivíduo" (GIDDENS, 2002, p. 54).

Tais atividades, embora sempre inéditas, não se dão como forma primeira de interação, ou seja, elas se dão a partir de tipificações históricas e pressupõem conhecimentos práticos - aspectos incorporados em habitus, que possibilitam (como conhecimento dado)

\footnotetext{
${ }^{3}$ Estilo de vida está sendo entendido aqui como “[...] um conjunto mais ou menos integrado de práticas que o indivíduo abraça, não só porque essas práticas preenchem necessidades utilitárias, mas porque dão forma material a uma narrativa particular da autoidentidade” (GIDDENS, 2002, p. 79).
} 
a emergência das próprias atividades, ou seja, as atividades só ocorrem como práticas sociais, marcadas por determinadas dinâmicas relacionais.

Sendo um dos aspectos que constituem as autoidentidades, as masculinidades se articulam com esses modos de configuração relacional na medida em que dizem respeito justamente a modos específicos de configuração das práticas em termos de relações de gênero social. Diversos autores (CONNELL, 2003; CONNELL; MESSERSCHMIDT, 2013; KIMMELL, 1998; WELZER-LANG, 2001 entre outros.) têm apontado para o fato de as masculinidades (e feminilidades) não serem uma espécie de "[...] entidade fixa encarnada no corpo ou nos traços da personalidade dos indivíduos, [mas] configurações de práticas que são realizadas na ação social [...]" (CONNEL, 2003, p. 72). Especificamente, as masculinidades “[...] são configurações de práticas estruturadas pelas relações de gênero [social]. Elas são inerentemente históricas e se fazem e refazem como um processo político que afeta o equilíbrio de interesse da sociedade e a direção da mudança social" (CONNEL, 2003, p. 72).

Considerando o jogo de forças históricas, no entanto, há a emergência do que Connel (2003) nomeia de masculinidade hegemônica - resultado da incorporação da forma historicamente mais "honrada" de ser homem num determinado tempo-espaço. Ela exige, nas palavras de Connell e Messerschmidt (2013, p. 245), "[...] que todos os outros homens se posicionem em relação a ela e legitima ideologicamente a subordinação global das mulheres aos homens” (CONNELL; MESSERSCHMIDT, 2013; KIMMELL, 1998; WELZER-LANG, 2001). Isso se dá por meio de símbolos (SCOTT, 1989), por construções que nem sempre dizem respeito a possibilidades reais de vivências, uma vez que "[...] a hegemonia trabalha em parte através da produção de exemplos de masculinidade [...], símbolos que têm autoridade, apesar do fato de a maioria dos homens e meninos não viver de acordo com eles" (CONNEL; MESSERSCHIMIDT, 2013, p. 263). Nesse caso, a masculinidade como um aspecto da autoidentidade se relaciona também com a linguagem na medida em que é constituída pelo processo de significação no interior das práticas.

Essas práticas, como atividades tipificadas, pressupõem formas típicas de acabamento discursivo da realidade, para além das masculinidades, ou seja, pressupõem tipificações discursivas estruturais, temáticas e estilísticas relacionadas à determinada atividade no âmbito de determinada esfera de atuação humana. Resumidamente: pressupõem determinados gêneros do discurso. Esses inscrevem posições discursivas as quais os sujeitos ocupam, mas podem também reconfigurá-las, recriá-las, dado o caráter sempre aberto da existência. É sobre a dimensão dos gêneros discursivos nas práticas que trata a próxima seção.

\section{OS GÊNEROS DO DISCURSO COMO DIMENSÃO DISCURSIVA DA REALIZAÇÃO DAS PRÁTICAS}

O conceito de gêneros discursivos é substancial para o tratamento das práticas sociais e a relação destas com a linguagem, que, aliás, lhe é intrínseca, e tem sido retomado por diversos campos de estudo (BAZERMAN, 2009; BAWARSCHI; REIFF, 2013). No âmbito da Linguística, Meurer (2002), por exemplo, precursor da perspectiva crítica de análise de gêneros no Brasil, mostra como uma narrativa pessoal como gênero tem desdobramentos sobre os modos de conceber o mundo, as relações sociais e a autoidentidade. Além disso, ele propõe que o estudo crítico dos gêneros seja um meio de reconstruir essas instâncias sociais.

Nesse viés, recentemente, no âmbito da Análise Crítica de Gêneros (ACG), Bonini tem agenciado o quadro teórico bakhtiniano para o tratamento do fenômeno, ação cada vez mais presente entre outros autores (Conf. MOTTA-ROTH; MERCUZZO, 2010; MOTTA-ROTH, 2013 entre outros), bem como a perspectiva faircloughiana e freireana para a definição do caráter crítico das análises em ACG (BONINI, 2013; 2014; 2017). Nessa perspectiva, o gênero tem sido entendido como uma unidade tipificada em termos de horizonte temático e estilístico-composicional na efetivação das práticas sociais.

Assim, a tipificação temática de um gênero diz respeito ao domínio de sentido que o gênero compreende, sendo este caracterizado pelo "[...] contato entre significação e realidade concreta em circunstâncias típicas” (BAKHTIN, 2003, p. 293). Em outras palavras, o tema se relaciona com "a realidade que dá lugar à formação de um signo" (VOLOCHINOV, 2014, p. 46). No âmbito do gênero, o tema é "[...] determinado não só pelas formas linguísticas que entram na composição (as palavras, as formas morfológicas ou sintáticas, os sons, as entonações), mas igualmente pelos elementos não verbais da situação” (VOLOCHINOV, 2014, p. 133). Ainda, o tema só existe como um recorte da realidade, sendo, por isso, saturado da expressão valorativa daquele que recorta (o autor) e, 
consequentemente, da esfera da qual emerge (MEDVIÉDEV, 2016). Esse aspecto é substancial frente às lutas pela hegemonia, uma vez que a luta por determinados recortes da realidade é também pela efetivação de determinadas configurações das práticas sociais.

Já a tipificação estilístico-composicional diz respeito às escolhas lexicais, fraseológicas e gramaticais em função da imagem do interlocutor e de como se presume sua compreensão responsiva ativa do enunciado. Diz respeito também à organização típica de determinado gênero em termos da relação entre interlocutores. Segundo Bakhtin (2003, p. 266), a estrutura composicional se refere à determinada unidade da composição, ou seja, determinados tipos de construção do conjunto, tipos de acabamento, tipos de relação do falante com outros participantes da comunicação discursiva. Essas "unidades", esses "tipos de acabamento", podem ser entendidos como espécies de fronteiras da atividade dialógica. Nas palavras de Bakhtin, "[...] o início e fim de uma obra, do ponto de vista da unidade da forma, são o início e o fim de uma atividade: sou eu quem começo e quem termino" (BAKHTIN, 1988, p. 63). Os limites formais de um enunciado são dados, assim, a partir do acabamento dado ao enunciado pelo seu autor, endereçado ao(s) interlocutor(es).

Segundo Bonini (2004), em termos de delimitação de fronteiras enunciativas para a caracterização de um gênero discursivo, é possível considerar ainda a autoria compartilhada de diferentes sujeitos que, conjuntamente, construiriam um único enunciado tipificado a partir de/em um gênero. É o caso da "audiência pública", da "aula", da "entrevista de rádio" etc. Nesse caso, trata-se do que Bonini (2004) nomeia de enunciado-recorte, isto é, fenômenos que pressupõem fronteiras não marcadas pela troca de turno de fala, mas por instâncias enunciativas mais abrangentes.

A delimitação do enunciado-recorte, segundo Bonini (2004), se dá a partir, não de um interlocutor que interage no interior de uma conversa, por exemplo, mas de um observador que delimita o enunciado por meio de critérios a partir dos quais traça o início e fim de um ritual interativo. Assim, tem-se, de um lado, o que Bonini (2004, p. 9) chama de "texto-ritual", ou seja, "uma unidade produzida por meio de uma rede de trocas entre enunciadores individuais", materializando o enunciado-recorte; e de outro lado, um texto simples (com apenas um enunciador) ou texto complexo (como uma unidade com uma cadeia hierárquica de enunciadores), materializando um enunciado-pleno (enunciado no sentido bakhtiniano).

Embora heterogêneas, tais formas de recortar e materializar os enunciados não prescindem dos aspectos constitutivos apontados por Bakhtin e discutidos até aqui, sobretudo no que tange às relações entre enunciado, gêneros discursivos, práticas sociais e autoidentidades. Em verdade, apenas apontam para a complexidade do fenômeno discursivo quando entendido em relação às práticas sociais. Aliás, as relações até aqui aventadas acerca da relação entre autoidentidades, práticas sociais e gêneros discursivos justificam a centralidade deste último conceito na ACG.

Assim, o conceito de gêneros discursivos se mostra substancial na análise de autoidentidades e especificamente de masculinidades enquanto tanto uma configuração de práticas quanto um modelo de "ser homem" (CONNELL, 2003). Afinal, sendo as masculinidades atravessadas por todas essas dimensões (inerentes às práticas), de sua análise podem emergir inteligibilidades tanto sobre as formas de existir como homem, quanto dos modos de inscrição dessas formas na estrutura social (que ocorre via estabilizações relativas de enunciados/eventos concretos).

\section{METODOLOGIA}

Estando sob o guarda-chuva das pesquisas em Linguística Aplicada, o presente estudo se debruça sobre problemas socialmente relevantes que têm a linguagem como um aspecto central (MOITA LOPES, 2006), buscando intervir sobre tais problemas a partir da reflexão crítica, da pesquisa científica. Especificamente, assume-se a perspectiva qualitativa (MASON, 1998) e agenciam-se instrumentos etnográficos para a geração de dados (observação participante, gravações em áudio, notas e diário de campo), que são descritos e interpretados (FAICLOUGH, 2003) à luz das postulações teóricas assumidas.

Assim, o problema social relevante é a recorrência dos diversos tipos de violência contra a mulher e sua relação com os modos de dar sentido às relações de gênero (gender) a partir de padrões hegemônicos de masculinidades e feminilidades (centrados em 
diversos tipos de violência). A partir disso, a reflexão se debruça sobre as práticas sociais que buscam intervir sobre o problema. Nesse caso, trata-se da prática do grupo socioeducativo para homens autores de violência contra a mulher, proposta como uma política pública fomentada pelo Sistema Único de Assistência Social (SUAS) e realizada pelo Centro de Referência Especializado em Assistência Social (CREAS), gerido pela Secretaria Municipal de Desenvolvimento Social (SEMUDES), numa cidade ${ }^{4}$ da região Sul do Brasil.

Essa política funciona no município desde 2004 e atende homens com idades e profissões variadas (Conf. Quadro 01), que tenham protagonizado situações de violência contra a mulher (especialmente no âmbito conjugal) e que acessam o SUAS por diferentes frentes. Desde 2014, o grupo atende também homens encaminhados compulsoriamente pelo Sistema Judiciário, em cumprimento de pena ou de medida protetiva de urgência. Ao longo dos 12 meses de pesquisa de campo, 45 homens passaram pelo grupo, sendo que desses, 31 participaram das sessões que compõem os dados de análise.

\begin{tabular}{|c|c|c|c|}
\hline Nome & Idade & Ocupação & Natureza do encaminhamento \\
\hline Alan & 43 & $\begin{array}{c}\text { Segurança } \\
\text { (desempregado) }\end{array}$ & $\begin{array}{l}\text { Juizado Criminal (Medida Protetiva de } \\
\text { Urgência/ Compulsória) }\end{array}$ \\
\hline Alberto & 43 & \begin{tabular}{|c|} 
Fiscal de transporte \\
escolar
\end{tabular} & $\begin{array}{l}\text { Juizado Criminal (Revisão processual } \\
\text { Compulsória) }\end{array}$ \\
\hline Alcides & 64 & $\begin{array}{l}\text { Microempresário } \\
\text { (aposentado) }\end{array}$ & $\begin{array}{l}\text { Juizado Criminal (Medida Protetiva de } \\
\text { Urgência vinculada à liberação de prisão } \\
\text { preventiva/ Compulsória) }\end{array}$ \\
\hline A lexandre & 51 & $\begin{array}{c}\text { Jardineiro } \\
\text { (desempregado) }\end{array}$ & $\begin{array}{l}\text { Centro de Referência em Assistência } \\
\text { Social/ CRAS (Espontânea) }\end{array}$ \\
\hline Álvaro & 43 & Pedreiro autônomo & $\begin{array}{l}\text { Juizado Criminal (Medida Protetiva de } \\
\text { Urgência/ Compulsória) }\end{array}$ \\
\hline Anderson & 24 & Garçon & $\begin{array}{l}\text { Juizado Criminal (Medida Protetiva de } \\
\text { Urgência/ Compulsória) }\end{array}$ \\
\hline Arthur & NI* & NI & $\begin{array}{l}\text { Juizado Criminal (Medida Protetiva de } \\
\text { Urgência/ Compulsória) }\end{array}$ \\
\hline Bernardo & NI & NI & $\begin{array}{l}\text { Centro de Reabilitação para Dependentes } \\
\text { Químicos (Espontânea) }\end{array}$ \\
\hline Beto & 30 & Mecânico & \begin{tabular}{|l}
$\begin{array}{l}\text { Juizado Criminal (Execução de pena/ } \\
\text { Compulsória) }\end{array}$ \\
\end{tabular} \\
\hline Caio & NI & NI & $\mathrm{NI}$ \\
\hline Carlos & 43 & Pedreiro & $\begin{array}{l}\text { Juizado Criminal (Medida Protetiva de } \\
\text { Urgência/ Compulsória) }\end{array}$ \\
\hline César & 67 & Aposentado & $\begin{array}{l}\text { Juizado Criminal (Medida Protetiva de } \\
\text { Urgência/ Compulsória) }\end{array}$ \\
\hline Cláudio & 28 & Auxiliar de cozinha & NI \\
\hline Diogo & NI & NI & $\begin{array}{l}\text { Centro de Reabilitação para Dependentes } \\
\text { Químicos (Espontânea) }\end{array}$ \\
\hline Edson & NI & Zelador & Conselho tutelar (Espontânea) \\
\hline Edvan & 34 & Motorista & $\begin{array}{l}\begin{array}{l}\text { Juizado Criminal (Revisão processual } \\
\text { Compulsória) }\end{array} \\
\end{array}$ \\
\hline Gean & 33 & \begin{tabular}{|c|} 
Operador em \\
empresa de \\
transformadores de \\
energia \\
\end{tabular} & $\begin{array}{l}\text { Juizado Criminal (Medida Protetiva de } \\
\text { Urgência/ Compulsória) }\end{array}$ \\
\hline Ilma & 35 & $\begin{array}{l}\text { Psicóloga - } \\
\text { facilitadora }\end{array}$ & Não se aplica \\
\hline Ivan & 43 & $\begin{array}{l}\text { Motorista em } \\
\text { licença-saúde }\end{array}$ & $\begin{array}{l}\begin{array}{l}\text { Juizado Criminal (Execução de pena/ } \\
\text { Compulsória) }\end{array} \\
\end{array}$ \\
\hline Jaime & 29 & Empresário & $\begin{array}{l}\text { Juizado Criminal (Medida Protetiva de } \\
\text { Urgência/ Compulsória) }\end{array}$ \\
\hline
\end{tabular}

${ }^{4} \mathrm{O}$ nome da cidade não será divulgado devido ao acordo firmado com os participantes em Termo de Compromisso Livre e Esclarecido (TCLE). 


\begin{tabular}{|c|c|c|c|}
\hline Jaime & 29 & Empresário & $\begin{array}{l}\text { Juizado Criminal (Medida Protetiva de } \\
\text { Urgência/ Compulsória) }\end{array}$ \\
\hline Lucas & 56 & Pedreiro & $\begin{array}{l}\text { Juizado Criminal (Medida Protetiva de } \\
\text { Urgência vinculada à liberação de prisão } \\
\text { preventiva/ Compulsória) }\end{array}$ \\
\hline Maicon & 32 & $\begin{array}{c}\text { Mecânico } \\
\text { (des empregado) }\end{array}$ & $\begin{array}{l}\text { Juizado Criminal (Medida Protetiva de } \\
\text { Urgência/ Compulsória) }\end{array}$ \\
\hline Marcos & 48 & Motoris ta & $\begin{array}{l}\text { Juizado Criminal (Medida Protetiva de } \\
\text { Urgência/ Compulsória) }\end{array}$ \\
\hline Matheus & NI & NI & $\mathrm{NI}$ \\
\hline Murilo & NI & NI & $\begin{array}{l}\text { Centro de Reabilitação para Dependentes } \\
\text { Químicos (Espontânea) }\end{array}$ \\
\hline Pietro & NI & Estudante & Outro** (Es pontânea) \\
\hline Roberto & 40 & $\begin{array}{l}\text { Ass istente Social e } \\
\text { profess or } \\
\text { universitário } \\
\text { (coordena o abrigo } \\
\text { de mulheres ) - } \\
\text { facilitador } \\
\end{array}$ & Não se aplica \\
\hline Robson & NI & NI & $\begin{array}{l}\text { Centro de Reabilitação para Dependentes } \\
\text { Químicos (Es pontânea) }\end{array}$ \\
\hline Sandoval & 53 & Pedreiro autônomo & $\begin{array}{l}\text { Juizado Criminal (Medida Protetiva de } \\
\text { Urgência) }\end{array}$ \\
\hline Saulo & 31 & $\begin{array}{c}\text { Repres entante } \\
\text { comercial }\end{array}$ & $\begin{array}{l}\text { Juizado Criminal (Medida Protetiva de } \\
\text { Urgência/ Compulsória) }\end{array}$ \\
\hline Silvia & 39 & $\begin{array}{c}\text { Psicóloga } \\
\text { (Coordenadora do } \\
\text { CREAS) - } \\
\text { facilitadora } \\
\end{array}$ & Não se aplica \\
\hline Silvio & NI & $\mathrm{NI}$ & $\mathrm{NI}$ \\
\hline Vaness a & 32 & $\begin{array}{l}\text { Profess ora - } \\
\text { pesquis adora }\end{array}$ & Não se aplica \\
\hline Vicente & 44 & Zelador & $\begin{array}{l}\text { Programa de Prevenção e Combate à } \\
\text { Violência Doméstica e } \\
\text { (Espontânea) }\end{array}$ \\
\hline \multicolumn{4}{|c|}{ * Não informou } \\
\hline
\end{tabular}

Quadro 1: Participantes (com nomes fictícios) por idade, ocupação e natureza do encaminhamento

Fonte: elaboração da autora com base em Soares (2018, p. 143)

Em termos organizacionais, o grupo é planejado a partir de um bloco de 12 sessões com cerca de 1 h30min cada, que ocorrem a cada 15 dias e cujas temáticas compreendem desde a "Lei Maria da Penha", passando por "Paternidade" até chegar a, explicitamente, "Questões de gênero (gender)". As sessões são planejadas para ocorrerem de maneira cíclica, de modo que os temas se repetem. No entanto, os dados apontam para um replanejamento constante a depender dos acontecimentos internos ao grupo e do próprio contexto social mais amplo. O grupo em pauta foi acompanhado via observação participante durante 12 meses, período em que se realizou a gravação em áudio de um bloco de 12 sessões consecutivas, que foram posteriormente transcritas, conforme Quadro 02 , e constituem os dados centrais da análise. Esses são referenciados ao longo da discussão da seguinte forma: Alexandre_S10L124135, em que "Alexandre" diz repeito ao interlocutor (quando há mais de um interlocutor, esses são identificados no corpo do próprio excerto e na referência uso o termo "Vários"); "S10" se refere ao número da sessão (sessão 10) e "L124-135" diz respeito ao intervalo de linhas da transcrição dessa sessão (linha 124 até a 135). Por fim, esclareço que os nomes dos participantes foram alterados em atendimento ao TCLE. 


\begin{tabular}{|c|c|}
\hline $\begin{array}{c}\cdots \\
? \\
, \\
\text { palavra } \\
\text { MAIÚSCULA } \\
\text { opalavra } \\
\text { >palavra< } \\
\text { <palavra> } \\
\text { :: ou ::: } \\
\text { [palavra] } \\
\text { ((incompreensível)) } \\
\text { (palavra) } \\
\text { (( )) } \\
\text { "palavra" } \\
\text { ((risos)) } \\
\text { ((riso)) }\end{array}$ & $\begin{array}{l}\text { pausa não medida ou interrupção de fala } \\
\text { entonação descendente ou final de elocução } \\
\text { entonação ascendente (pergunta) } \\
\text { pausa, entonação de continuidade } \\
\text { ênfase } \\
\text { fala em voz alta ou muita ênfase } \\
\text { palavra ou trecho em voz baixa } \\
\text { fala mais rápida } \\
\text { fala mais lenta } \\
\text { alongamentos } \\
\text { falas sobrepostas } \\
\text { fala não compreendida } \\
\text { fala provável } \\
\text { comentário do analista, descrição de atividade } \\
\text { não verbal } \\
\text { fala relatada, reconstrução de um diálogo } \\
\text { riso não discreto ou gargalhada } \\
\text { riso discreto }\end{array}$ \\
\hline
\end{tabular}

\section{A SESSÃO DE GRUPO SOCIOEDUCATIVO}

A prática do grupo socioeducativo para homens autores de violência contra a mulher (HAV) se organiza a partir do gênero sessão de grupo socioeducativo. Nesse caso, trata-se de um enunciado-recorte (BONINI, 2004): um bloco interativo regular (texto-ritual) realizador de uma determinada prática e no qual, no caso da sessão, são encaixados outros gêneros (enunciado-plenos), como notícias, lista de presença, documentário etc. Nesta discussão, então, apresentarei as dimensões temática e estilístico-composicional desse gênero, bem como seu modo de funcionamento, apontando para a relação entre tais configurações e a (re)construção de autoidentidades, especialmente de masculinidade(s).

\subsection{A DIMENSÃO TEMÁTICA}

Segundo Bakhtin (2003, p. 261), os gêneros discursivos refletem as condições específicas e as finalidades de cada campo de atividade humana. Isso se dá também a partir de seu conteúdo temático, isto é, das formas de dar acabamento ao aspecto da vida que é trazido ao/construído no enunciado (MEDVIÉDEV, 2016, p. 195). Isso implica a orientação para esse aspecto da realidade a partir de um determinado lugar, de um horizonte de valores (MIEDVEDEV, 2016; VOLOCHINOV, 2014; BAKHTIN, 2003). Nesse caso, a finalidade da assistência social de intervir no contexto de vidas das pessoas deriva do entendimento de que essa intervenção é possível, necessária e legítima, sendo, portanto, a orientação para a mudança nas relações de gênero social o recorte temático do grupo em análise.

Em outras palavras, considerando que as finalidades da esfera da Assistência Social dizem respeito ao préstimo de assistência a famílias/indivíduos, é possível identificar essas finalidades materializadas na tematização de aspectos relativos à vida dessas pessoas e, no caso do grupo, especialmente suas formas de convívio com as mulheres (colegas de trabalho, filhas, irmãs e especialmente ex/esposas e/ou ex/namoradas). Assim, a dimensão temática da sessão diz respeito à necessidade de mudança nas relações de gênero (social) pautadas na dominação masculina, especialmente aquelas das quais os HAV participa(ra)m.

Essa orientação deriva da esfera e também do acabamento discursivo que é dado pelos facilitadores do grupo: um assistente social e duas psicólogas, conforme ilustram os excertos abaixo: 
(1)

Porque a pessoa casou, tem filho... daí de repente... aí em 10 anos reavaliou e... agora quero trabalhar, fazer outra coisa... né? Quero outra coisa... ((incompreensível)) a gente muda as prioridades na vida em determinados momentos da vida, né?... não é porque fez uma coisa uma vez que vai continuar semp... daquele jeito... até morrer... né?... (Roberto_S01L226-232)

([...] trazer isso pra nossa realidade, né? Que que... qual é a nossa interação com o outro dentro de casa que pode também tá contribuindo pra, ter uma relação tensa ou uma relação de harmonia ou de tranquilidade, né? [...] como que a gente pode, tá, mudar e pra gente também poder ressignificar essa história, qual é o nosso papel, qual é a nossa responsabilidade e qual é o nosso lugar diante disso, né? (Roberto_S04L241-244;256-260).

No excerto (1), Roberto, um assistente social que é funcionário do CREAS e facilitador do grupo, enfatiza que a mudança é uma possibilidade na vida. Ao reforçar que "a gente muda as prioridade na vida” a partir de uma "reavaliação" da própria vida, Roberto aponta também para o caráter reflexivo da constituição de si, algo relacionado diretamente com os estilos de vida e escolhas que se faz ao longo da própria trajetória (GIDDENS, 2002). Nesse sentido, valora positivamente a mudança a partir de um discurso que legitima a possibilidade de agir sobre a própria vida, de (re)construí-la. No excerto (2), ele apela para que os homens reflitam acerca de sua própria responsabilidade nas situações de violência, construindo um discurso que vai de encontro àquele que culpa exclusivamente a mulher pelas situações de violência (por não ter feito comida, não ter cuidado dos filhos, ter usado roupa curta etc.).

Esse horizonte mostra-se também nos assuntos elencados para discussão ao longo das sessões, já que apontam para a necessidade de mudanças nas relações de gênero social e, consequentemente, nas autoidentidades. Assim, em cada uma das sessões, o tema das relações de gêneros sociais, sob orientação da necessidade de mudanças daquelas pautadas na dominação, é tratado a partir de um aspecto. Nesse caso, quando se propõe discutir frases de cunho sexista que mulheres ouvem numa cultura pautada na dominação masculina, por exemplo, discutem-se as concepções de feminilidades e sua relação a masculinidades. Abaixo, estão listados os assuntos elencados pelos organizadores do grupo em cada uma das sessões.

1. Clichês acerca das relações de gênero;

2. Estereótipos e preconceitos de gêneros e outros papéis sociais;

3. Igualdade de gêneros, masculinidades e feminilidades;

4. Violência contra a mulher, racismo e ciúme;

5. Planejamento de vida;

6. Lei Maria da Penha, Violência contra a mulher;

7. Masculinidade(s), feminilidade(s), Relações de gênero;

8. Violência contra a mulher;

9. Violência contra a mulher;

10. Violência contra a mulher e Masculinidades;

11. Gênero e religião;

12. Educação e gênero;

O modo como esses assuntos são abordados no grupo centra-se principalmente na conversa, que estrutura a sessão e explora aquilo que Giddens (1991, p. 45) nomeia de reflexividade ${ }^{5}$, isto é, o fato de que "[...] as práticas sociais são constantemente examinadas e reformadas à luz de informação renovada sobre estas próprias práticas, alterando assim constitutivamente seu caráter”, aspecto ilustrado também pelos excertos (1) e (2), proferidos por peritos de sistemas abstratos (GIDDENS, 2002). Embora esse seja um aspecto inerente à relação entre práticas sociais e linguagem, por exemplo, conforme se entende com Chouliaraki e Fairclough (1999), na modernidade tardia há, segundo Giddens (1991), a sua radicalização.

\footnotetext{
${ }^{5}$ Veja-se que muitos desses grupos no Brasil e no mundo recebem o nome de "grupo reflexivo", ressaltando justamente o teor reflexivo da prática.
} 
No âmbito do grupo, esse processo é fomentado de diferentes formas pelos facilitadores, vinculado-se à estruturação arquitetônica da sessão. A principal forma dessa intensificação é o questionamento de discursos que legitimam certas masculinidades e feminilidades centradas em relações de dominação. Isso ocorre tanto por meio de perguntas diretas e indiretas quanto por meio de enunciados em tom explicitamente avaliativo, tom de contra-argumentação e de co-construção de narrativas pessoais dos participantes, interpretando com eles a própria história ${ }^{6}$.

Esses discursos entram em pauta por meio dos gêneros e assuntos presentes nos materiais (outros gêneros) utilizados como disparadores de discussão durante as sessões e, nesse caso, articulam-se diretamente como a estrutura estilístico-composicional do gênero. Assim, em cada uma das sessões, o tema das relações de gêneros sociais, sob orientação da necessidade de mudanças das relações pautadas na dominação, é tratado a partir de certo aspecto. Isso se dá por meio das atividades que visam justamente à reconfiguração dessas relações. É sobre essa estruturação que trata a seção seguinte.

\subsection{A ESTRUTURA ESTILÍSTICO-COMPOSICIONAL}

Conforme apontei anteriormente, a sessão de grupo socioeducativo é estruturada centralmente por meio da conversa. Essa é organizada pelo/as facilitador/as, que ocupam o lugar de peritos (GIDDENS, 2002), planejando e conduzindo o diálogo. Nesse caso, as posições desses interlocutores são dadas pelas posições que esses ocupam na esfera de atividade na qual se encontram (assistente social, psicólogas e assistidos), também pela posição de gênero social que perfomatizam nesse contexto (homens e mulheres) e pelas classes sociais a que pertencem ${ }^{7}$.

Em termos relacionais, entre participantes e facilitador/as, há uma assimetria constitutiva, que é figurada, por exemplo, pelo fato de a organização e a condução da sessão serem sempre realizadas pelo/as facilitador/as e pelo fato de os participantes se dirigirem em vários momentos mais ao/às facilitador/as do que aos pares do grupo (seja pelo direcionamento corporal seja mais explicitamente por meio de réplicas no diálogo). Essa hierarquia é apontada, inclusive, pelos HAV, quando avaliam o modo de participação assumido na interação, conforme ilustra o excerto abaixo, no qual Ivan justifica a interrupção da fala de Ilma pela posição que esta, na avaliação de Ivan, ocuparia na sessão de grupo.

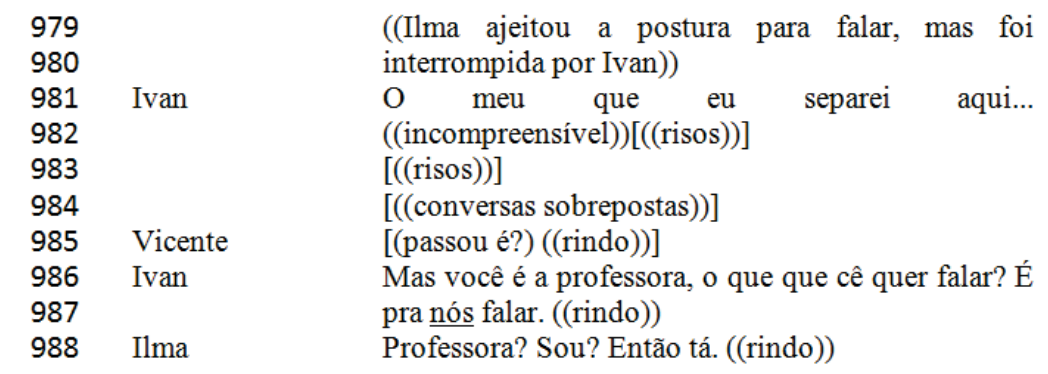

(Vários_S14L979-988)

Embora não se descarte a possibilidade de estar ocorrendo aqui aquilo que comumente se nomeia de manterrupting, ou seja, a prática de interrupção pelos homens das falas das mulheres em interações mistas, baseadas na naturalização da dominância dos primeiros sobre as segundas, inclusive sobre os turnos de fala; essa interrupção específica aponta também para certa significação das posições que cada um ocupa no grupo, o que pode ser percebido pela justificativa dada por Ivan para a interrupção.

\footnotetext{
${ }^{6}$ Por motivos de espaço, apenas alguns desses aspectos serão mais bem abordados na seção 5.3, quando analiso mais detalhamento um excerto maior da sessão.

${ }^{7}$ Veja-se que a maioria dos participantes pertence a estratos socioeconômicos inferiores, considerando suas ocupações e a renda média atrelada a tais atividades (Conf. Figura 1).
} 
Ivan parece acreditar que Ilma, mesmo estando na vez de falar ${ }^{8}$, não o faria, haja vista que estava conduzindo a sessão como profissional do CREAS (psicóloga), e não falando de si, como os demais participantes (HAV). Ele a chama de "professora" (linha 986), uma nomeação que pode ser sustentada pelas ações que o/as facilitador/as exercem no grupo, cujos aspectos retomam a prática escolar, especialmente porque há a condução do grupo em atividades planejadas com objetivos definidos, semelhantemente ao que ocorre na instituição escolar tradicional. Tal nomeação aponta para a relação professor(a)/aluno(a), na qual Ivan seria, então, o aluno. Daí também se justifica, por exemplo, o termo "socioeducativo" na nomeação do grupo.

Veja-se, no entanto, que Vicente, o participante mais antigo - já mais familiarizado com as práticas da sessão - ri da situação e aponta para o equívoco de Ivan (passou é? - linha 985). Tal fato mostra que Vicente, tal como Ilma, esperava que esta última falasse, uma vez que, apesar das posições definidas pela esfera para cada um dos/as envolvidos/as no grupo, a lógica hierárquica das relações é constantemente tensionada pelo modo de efetivar a prática em cada uma das sessões, ou seja, pelos eventos singulares dessa prática, fato com o qual Vicente está familiarizado por ser um membro mais experiente, o que marca também diferenças de posicionamentos entre os próprios HAV como interlocutores.

No desenvolvimento desse diálogo, ao final das falas dos participantes, Ilma retoma a palavra e fala sobre suas brincadeiras de infância, efetivando a prática do grupo de modo a colocar-se como alguém também atravessada pelas questões discutidas com os participantes (HAV). Essa é também uma estratégia de aproximação assumida pelo/as facilitador/as e figura aquilo que Fairclough (2001) nomeia de democratização, isto é, estratégia discursiva que busca reconfigurar nas interações certas hierarquias sociais.

Ao longo das sessões, essa estratégia é recorrente. Conforme notas de campo (17/08/2016), em outra sessão, Ilma questiona, por exemplo, por que ela, Silvia, Roberto e também eu não fazemos as atividades que os participantes estão fazendo, mostrando-nos como quem também possui representações acerca do que estava sendo discutido.

Esse caráter democrático constitui ainda o modo de relação do/as falicitador/as entre si, o que é figurado, por exemplo, pela negociação sobre a condução do grupo, conforme discuto adiante acerca da abertura da sessão.

Por fim, a relação dos participantes (HAV) entre si é marcada pelo fato de todos compartilharem a vivência de situações de violência contra a mulher e estarem no grupo justamente devido a isso, seja de modo voluntário ou compulsório. Apesar disso, estar de modo voluntário ou compulsório mostrou-se um marcador de diferenciação entre os participantes no que tange à adesão ao grupo, à orientação às/ao facilitador/as e à valoração dessa prática, conforme ilustram os excertos (4) e (5).

(4)

$\begin{array}{lll}665 & \text { Marcos } & \text { Ele disse que faz oito anö que ele acompanha } \\ 666 & & \text { aqui... ((para Vanessa)) } \\ 667 & \text { César } & \text { Só por causa do café, né? } \\ 668 & \text { Arthur } & \text { Só por caus:: ((risos)) ((repetindo a fala de César)) } \\ 669 & \text { Alcides } & \text { O café que é preto eu não ((incompreensível)) } \\ 670 & \text { Vicente } & \text { Não não, porque eu sou bem-vindo aqui } \\ 671 & & \text { ((incompreensível)). }\end{array}$

(Vários_caféinicial_S07L665-671)

E a gente só tamo nessa... na verdade todos os home tão aqui eles só tão aqui porque tem um juiz lá em cima que determinou uma ordem, né?

(Álvaro_S10L1855-1857)

${ }^{8}$ Todos estavam sentados em roda e cada um ia falando seguidamente sobre suas brincadeiras de infância. 
Nos excertos, respectivamente, Vicente (participante voluntário) enfatiza estar no grupo pelo sentimento de acolhimento e amizade que tem principalmente com o/as facilitador/as (linha 670) ao passo que Álvaro (participante compulsório) demonstra sua não adesão ao grupo, vinculando sua frequência (e dos demais encaminhados) apenas ao cumprimento de uma ordem judicial.

Além dessas valorações categóricas, os dados apontam para outras que congregam modalizações acerca da positividade e negatividade do grupo e da rede de práticas que o circundam; as da esfera judicial, por exemplo. Nesse caso, o excerto (6) ilustra a valoração acerca da Lei Maria da Penha (11.340/2006). Embora se articule com a ideia de punição, a execução legal, a imputação da lei cria também um discurso de legitimidade do Poder Judiciário.

(6)

$((\ldots))$ hoje é isso que tô aprendendo... entã::o em tudo para e... e quando cê:::: o que que tá dando mais... o que que a lei hoje, a:: (que) funciona? Realmente, é a Maria da Penha. ...o casal, hoje é:: Maria da Penha. ((...)) (Robson_S14L1691-1695)

Ao afirmar que a lei que funciona hoje é a Maria da Penha, Robson reconhece indiretamente as demandas das mulheres por respostas institucionais como legitimadas socialmente. Além disso, atrelada à medida protetiva, como é o caso da maioria dos encaminhamentos ao grupo, essa resposta judicial é vista como rápida, fazendo com que se transcenda, ao menos no nível discursivo e imediato, a questão da morosidade da justiça, que desencadeia quase sempre na prescrição processual (LEITE; LOPES, 2013, p. 24).

Além das relações entre os interlocutores, compreender a estrutura estilístico-composicional implica traçar as fronteiras enunciativas da sessão de grupo, que podem ser mensuradas em termos de estruturação ritual (BONINI, 2004). Nesse sentido, é possível recortar a sessão, traçando suas fronteiras na abertura e no fechamento, que são indicialmente marcados, podendo ser recuperados por meio das marcas linguísticas que mantêm uma relação de contiguidade real como contexto mais imediato da situação (HANKS, 2008, p. 95). Entre essas fronteiras, a sessão é constituída por outros dois momentos: a apresentação de si e a atividade, sendo esse último o que ocupa mais tempo e pode ser subdividido em i) apresentação/explicação e ii) execução/discussão. Em termos sequenciais, o texto-ritual se organiza, então, em: i) abertura, ii) apresentação de si, iii) atividades e iv) fechamento (conf. quadro 3 adiante).

\begin{tabular}{|c|c|c|}
\hline \multicolumn{2}{|c|}{$\begin{array}{c}\text { Aspectos composicionais da sessão } \\
\text { de grupo socioeducativo }\end{array}$} & Marcadores indiciais \\
\hline \multicolumn{2}{|r|}{ Abertura } & "Podemos começar?” (Roberto_S2L1) \\
\hline \multirow{2}{*}{\multicolumn{2}{|c|}{ Apresentação de si }} & $\begin{array}{l}\text { "Acho que é legal a gente fazer uma } \\
\text { apresentação" (Roberto_S02L8) }\end{array}$ \\
\hline & & ${ }^{\circ}$ Meu nome é Cláudio ${ }^{\circ}$. (Cláudio_S02L53) \\
\hline \multirow{6}{*}{ Atividades } & \multirow[b]{2}{*}{ Apresentação/explicação } & $\begin{array}{l}\text { "Hoje a atividade ela tá direcionada pra } \\
\text { questão dos nossos preconceitos, né?" } \\
\text { (Roberto_S02L82-83) }\end{array}$ \\
\hline & & $\begin{array}{l}\text { "Então hoje o tema do grupo é trabalhar um } \\
\text { pouco isso. Pra isso, tá, a gente vai... vai... } \\
\text { é... distribuir uma tarja... tá... pra colocar na } \\
\text { testa e a pessoa que receba essa tarja não } \\
\text { vai saber o que tá escrito." } \\
\text { (Roberto S02L91-92) }\end{array}$ \\
\hline & \multirow{4}{*}{ Execução/ discussão } & $\begin{array}{l}\text { Roberto: Dá pra sobreviver com o que tu } \\
\text { ganha? ((para Alan)) }\end{array}$ \\
\hline & & Alan: Cara, deve dá, né? \\
\hline & & Roberto: Éh? \\
\hline & & $\begin{array}{l}\text { Alan: [Eu sou uma pessoa pulso firme. } \\
\text { Profissional ((risos)) (Vários_S02L254- } \\
\text { 257) }\end{array}$ \\
\hline
\end{tabular}




\begin{tabular}{|l|l|} 
& $\begin{array}{l}\text { E daí se colocando no lugar do } \\
\text { homossexual, como que é::: sentir esse } \\
\text { preconceito das pessoas? ((para Edson)) } \\
\text { (Silvia S02L429-430) }\end{array}$ \\
\hline \multirow{5}{*}{ Fechamento } & $\begin{array}{l}\text { Tá.] Assim a gente já tá no prazo, um } \\
\text { minutinho, dois no máximo. } \\
\text { (Silvia S02L1613) }\end{array}$ \\
\hline & $\begin{array}{l}\text { Então... Até daqui a quinze dias ... hã::: será } \\
\text { que vai ter feriado? Vai, né? } \\
\text { (SilviaS02L1690-1693) }\end{array}$ \\
\hline Então é isso, gente. (Roberto_S03L825) \\
\hline
\end{tabular}

Quadro 3: Aspectos composicionais da sessão e seus marcadores indiciais

Fonte: Soares (2018, p. 274)

A Abertura acontece geralmente com um chamamento dos participantes pelo/as facilitador/as, com expressões que marcam o "início oficial" da sessão do grupo (Podemos começar?; Acho que começa então etc.). Conforme mostram os excertos abaixo, isso é sempre "negociado" entre Silvia e Roberto, os facilitadores mais ativos na direção da sessão.

(7)

$\begin{array}{ll}\text { Roberto } & \text { Podemos começar? } \\ \text { Silvia } & \text { Sim ((incompreensível)) } \\ \text { Alan } & ((\text { incompreensível)) por ((Nome de uma cidade } \\ & \text { vizinha)). É mais tranquilo. Mais barato. } \\ \text { Roberto } & \text { Então tá, gente, boa tarde. } \\ & ((\text { Todos os presentes respondem "boa tarde" } \\ & \text { alternadamente.)) }\end{array}$

(Vários_S02L1-7)

(8)

$\begin{array}{rll}1 & \text { Silvia } & \begin{array}{l}\text { Vocês já assinaram a lista? } \\ 2\end{array} \\ 3 & \text { Beto } & \text { Não sei... ((incompreensível))três? } \\ 4 & \text { Silvia } & \text { A gente pode começar, viu? } \\ 5 & \text { Roberto } & \text { Po::de. } \\ 6 & \text { Roberto } & \text { Deixa eu pegar ((incompreensível)) } \\ \text { (Vários } & \text { S04L1-6) } & \end{array}$

Essa negociação entre Roberto e Silvia ilustra um tipo de relação democrática possível entre diferentes sujeitos (nesse caso, entre homens e mulheres, a partir do ponto de vista dos HAV). Veja-se que, sendo ambos facilitadores e ocupando a mesma posição hierárquica no grupo, estão sempre negociando suas decisões. Na abertura nem ele nem ela iniciam a sessão sem o "aval" do/a companheiro/a.

A inserção dos HAV em práticas em que haja relações de gêneros sociais que não se pautem na dominação masculina via violências de diversos tipos pode ser positiva e contribuir para que esses percebam esse tipo de relação como possível. Se práticas sociais são sempre significadas a partir de outras práticas (CHOULIARAKI; FAIRCLOUGH, 1999), então é possível que os significados acerca das relações na prática do grupo sejam levados a atuar em outras práticas, ressignificando-as.

O segundo momento da sessão, isto é, a Apresentação pessoal, ocorre quando há novos integrantes no grupo. Nele, cada um dos participantes se apresenta, dizendo seu nome e, caso queira, mais alguma informação que julgar importante. Dentre doze sessões que constituem os dados de análise, esse tipo de apresentação correu em sete delas. Em quatro dessas sessões as apresentações começaram pelo/as facilitador/as e nas outras três por diferentes participantes do grupo. As informações focalizadas foram (das mais às menos recorrentes): i) nome, ii) ocupação profissional, iii) motivo/tempo de vinculação ao grupo iv) idade, v) endereço, vi) expectativa/avaliação do grupo, conforme ilustram os excertos abaixo. 
Meu nome é Marcos, trabalho de motorista, e::: é o segundo dia que eu tô vindo aqui, segunda vez... tô gostando. É bom. Tá limpando a::: memória (digamos assim). (Marcos_S07L364-366)

(10)

Isso aí pessoal, boa tarde, meu nome é Alexandre, moro na ((nome do bairro)) e:: já... já tô uns... uns três meses, acompanhei ano passado e agora tô voltando aí, né? E os novatos que sejam bem-vindos, né? Possa tirar o melhor aproveito possível, né... porque é muito importante. (Alexandre_S06L41-46)

\begin{tabular}{|c|c|c|}
\hline $\begin{array}{l}117 \\
118 \\
119 \\
120\end{array}$ & Arthur & $\begin{array}{l}\text { Meu nome é Arthur, trabalho numa transportadora } \\
\text { de noite... tô aqui, simplesmente porque minha ex- } \\
\text { mulher me meteu uma me... uma medida... como é } \\
\text { que é...? }\end{array}$ \\
\hline 121 & Ilma, Vanessa e Silvi & Protetiva? \\
\hline $\begin{array}{l}122 \\
123 \\
124 \\
125 \\
126\end{array}$ & Arthur & $\begin{array}{l}\text { Protetiva. Sem mais, sem menos... mas vou dizer o } \\
\text { quê? Inocente ninguém é, alguma culpa a gente vai } \\
\text { ter, uma palavra, um, num calor duma discussão, tu } \\
\text { vai se atravessar uma palavra que a pessoa vai } \\
\text { entender errado. }\end{array}$ \\
\hline 127 & Silvia & Ham... \\
\hline $\begin{array}{l}128 \\
129 \\
130 \\
131\end{array}$ & Arthur & $\begin{array}{l}\text { Entendeu? Nós nem um momento... eu tive intenção } \\
\text { de fazer nenhum mal pra ela, muito menos pra meus } \\
\text { filhos. Agora eu tenho que vir aqui três meses, eu } \\
\text { acho que que nem a senhora falou pra mim... }\end{array}$ \\
\hline $\begin{array}{l}132 \\
133 \\
134\end{array}$ & $\begin{array}{l}\text { Silvia } \\
\text { Arthur }\end{array}$ & $\begin{array}{l}\text { Sim. } \\
\text { Então vou tentar provar, que não é só... tu quer } \\
\text { conhecer tua mulher, se separa dela... aí tu vai }\end{array}$ \\
\hline 38 & Silvia & $\begin{array}{l}\text { conhecer... ela faz de tudo pra te prejudicar ... tudo, } \\
\text { tudo... sabe? } \\
\text { ((silêncio }-3 \text { segundos)) } \\
\text { Vamos seguir então? }\end{array}$ \\
\hline
\end{tabular}

(Vários_S07L117-138)

Embora o fato de os facilitadores iniciarem as apresentações de si em algumas sessões pudesse configurar em um modelo do que poderia ser dito, em nenhum momento houve a definição explícita do que deveria ser dito, de modo que as informações focalizadas pelos participantes ilustram aquilo que esses julgam pertinente dizer sobre si nesse contexto.

A recorrência da informação profissional mostra que esse é um aspecto de identificação para esses sujeitos e responde à estruturação social capitalista. Se comparado à história das masculinidades (conf. CONNELL, 2003; NOLASCO, 1993), escrever-se como trabalhador é um modo de construção positiva de si, já que o discurso de "homem trabalhador" constitui uma masculinidade valorizada socialmente, especialmente a partir da Modernidade.

O quarto momento da sessão é o que nomeei de Atividade. Este é organizado em dois blocos, um de apresentação da proposta e outro de execução. O primeiro consiste numa explicação do que será feito, explicitando também, algumas vezes, objetivos e justificativas da atividade e esclarecendo dúvidas. O segundo bloco é a execução da atividade. Essas ações centram-se, principalmente, na discussão sobre algum tema desencadeado por uma atividade de leitura de um texto (escrito em linguagem verbal, em vídeo etc.) e compreende a maior parte da sessão. Durante esse momento é quando mais ocorrem reenquadramentos de outros gêneros, de diferentes esferas, ou seja, ocorre a reenunciação, em termos bakhtinianos.

Os dados apontam que os gêneros trazidos como desencadeadores das atividades são recorrentemente de esferas especializadas (Lei, notícia, documentário...), gêneros secundários (BAKHTIN, 2003). Já os gêneros que emergem na interação, que não são fruto do 
trabalho de planejamento da sessão, dizem respeito principalmente a contextos de conversas cotidianas, não institucionalizadas (piada, clichê, o ditado popular e a narrativa pessoal), gêneros primários (BAKHTIN, 2003). Esse momento será explorado com mais detalhes adiante, quando discuto o funcionamento da sessão.

Por fim, o Fechamento ocorre ao final da atividade e é marcado geralmente por expressões específicas (“É. Temos que encerrar..."; "Então... Até daqui a quinze dias..."). Tal “marcação", às vezes, inicia por meio de gestos, como levantar-se, guardar o material usado ou tomar café (S04L1662, abaixo), embora esses sempre sejam acompanhados por falas que apontam para o fim da sessão (e para o "planejamento" da próxima - S04L1663), conforme ilustrado abaixo.

$\begin{array}{lll}1661 & \text { Vicente } & \text { E ela é assim ((rindo)) } \\ 1662 & & \text { ((alguns vão se levantando para tomar café)) } \\ 1663 & \text { Silvia } & \text { Gente, dia } 7 \text { de dezembro é o último dia. Não } \\ 1664 & & \text { faltem, por favor, vai ser bem legal. }\end{array}$

(Vários_S04L1661-1664)

Com intuito de mostrar mais detalhadamente a dinâmica do gênero sessão de grupo socioeducativo, materializado em texto-ritual, objetivo discutir um excerto mais longo de uma das sessões do grupo, apontando para o modo de funcionamento dos aspectos temático e estitlístico-composicional apresentados até aqui e sua relação com a constituição de masculinidades, violência contra a mulher e práticas sociais. Nesse caso, explorarei principalmente a estratégia de reenquadramento de gêneros discursivos que é assumida no funcionamento do grupo.

\subsection{O FUNCIONAMENTO}

A recontextualização (FAIRCLOUGH, 2003) é a ação mais recorrente na sessão. Os gêneros estrategicamente recontextualizados são escolhidos pelos facilitadores como disparadores de discussão e trazidos das diversas esferas de atividade (judiciária, midiática, familiar etc.) para a esfera da assistência social, para a prática do grupo socioeducativo e, especificamente, para dentro do gênero sessão de grupo socioeducativo. Esse processo de recontextualização, ou de reenunciação (em termos bakhtinianos), é constitutivo da linguagem, já que caracterizado pelo dialogismo (BAKHTIN, 2003; VOLOCHINOV, 1929), mas se torna um aspecto ainda mais substancial na Modernidade tardia.

Afinal, explica Giddens (2002), com o desenvolvimento das tecnologias de comunicação, a recontextualização tem sido usada, inclusive, como uma tecnologia de exercício de poder para ação em tempo e espaços estendidos (FAIRCLOUGH, 2003). No entanto, pode também, contraditoriamente, fazer emergir novas formas de resistência que agem igualmente em tempos e espaços estendidos (FAIRCLOUGH, 2001). O excerto analisado a seguir, no qual a notícia "Globo não consegue combater machismo explícito de Marcos dentro do BBB” 9 é recontextualizada, aponta para os efeitos desse processo em relação aos sentidos acerca da violência contra a mulher e de masculinidades. Vejamos.

(13)

${ }_{9}^{9}$ Disponível em: http://entretenimento.r7.com/blogs/odair-braz-jr/criticas/globo-nao-consegue-combater-machismo-explicito-de-marcos-dentro-do-bbb-0604-2017/. Último acesso em 19 jan. 2018. 
Ivan

Edvan

Álvaro

Ilma

Álvaro

Ilma

Álvaro

Edvan

Ilma

Álvaro

Ilma
[A minha notícia é sobre o Big Brother, aquele cara.]

[como a gente reproduz isso ainda...]

Tá, vamo lá.

Ah isso que queria.

[Vamo seguir então], a outra.

[Vamo lá.]

O Marcos, né, do Big Brother, ele também é médico

acho esse cara,né?

Ele é::: cirurgião plástico.

Eu nem sei.

Eu não::: eu não acompanho Big Brother, mas eu vi

na.

Eu também não.

propaganda que ele era médico e daí que ele... acho que o a Globo tirou ele, né, do:.: por ele ter sido...

[A delegada que tirou .]

[Ele saiu, é.]

Uma delegada foi buscar ele.

Ah, a delegada foi buscar?

É, ele foi, é que::: agrediu, ele não agrediu , mas ele... é::.....

Coagiu?

[((incompreensível))]

[Coagiu ela], diminuiu ela ele disse que... que era feio mulher tá segurando uma garrafa, bebendo que::: isso era coisa...

Re... na verdade repreendeu.

[Na verd...]

[E aí ele...]

((conversas sobrepostas))

((incompreensível))pras as outras meninas também ele aprontou pra todas elas lá e... e depois ele andou::: quase que, não, só não bateu acho que porque ele sabia que tava na TV, né, mas ele::: ele segurou ela pela mão lá num canto...

$>$ E meteu o dedo na cara dela. $<$

e::: fazia com o dedo assim ((encena o que diz)) na cara dela e daí:: pessoal caiu em cima, né?, e tiveram que tirar ele porque..

'Nã(o), ele repreendeu.

Todos vocês viram essa notícia?

Eu não vi, mas eu já vi por cima no face assim.

É. É... uma repreensão é:: é uma coisa diferente se a gente for pensar, né, a repreensão é o que a gente faz com os nossos filhos, né? ["não faz isso, não faz aquilo".]

[Sim, mas ali::] agrediu com uma repreensão, [né?]

[É.]

["não faz..."]

Ele agrediu com a repreensão. É que (que nem eu vou querê) parar você.

É uma violência, né? 
Álvaro

Ilma

Álvaro

Edvan

Ilma

Álvaro

Ilma

Álvaro

Ilma

Álvaro

Vanessa

Álvaro

Vanessa

Álvaro

Ilma

Vanessa

Álvaro

Edvan

Ilma

Álvaro

Ilma

Álvaro

Ilma

Álvaro

Ilma

Edvan

Ilma

Álvaro

Roberto

Silvia

Álvaro

Silvia

Edvan
É uma violência eu querer parar você, para você se eu não parar verbalmente eu vou tentar te por [uma:::]

[I:*:sso]

imposição de macho ali pra:: tu.

É.

E isso é uma violência .

Isso é uma violência.

Exato, exat...

Violência como repreensão.

De um sobre o outro... [tanto de um quanto o outro.]

[E é uma violência que não, pra repreender você,] pra você não passar dali.

Mas aí o fat... pelo fato de ser repreensão, o senhor tá assim... tá dif... diferenciando, né? Que tem violência que daí não seria pra repreensão e outras que seriam pra repreensão?

Sim.

Então as que servem pra repreensão, como pra educar os filhos, se justificam então?

Não... você justificá o teu filho é diferente como essa atitude dele. Ali ele quis se impor, no meio da sociedade que ele go... governava o bagulho ali.

[Hãm::: ah, lógico.]

[Então não faz diferença] se for pra repreender ou não, né? A questão é que houve uma agressão, né? [Houve.]

[Éh::]

É, e até bem importante o senhor falou agora que, o que que eu penso? "Ele qui... ele quis se impor"... ótimo, eu concordo que ele também quis se impor, porque ele quis diminuir o outro...

Sim::.

Ela não foi como uma repreensão ... ele qui... queria estar a... acima [dela.]

[Acima] dela... a qualquer preço.

Exatamente... entende qual é a diferença? Se fosse repreensão não, repreensão é pra, auxiliar o outro, ajudar o outro a se comportar de uma maneira melhor...

$>$ Mas tem gente que não entende assim. $<$

É. É por isso que a gente tá aqui, justamente pra isso, pra gente abrir... né? o âmbito, pensar uma coisa, será que não é... será que é dessa forma? Será que essa é a melhor forma de agir? Será que a gente faria a mesma coisa se tivesse no lugar?

É, as vezes até faria porque acha que... que é isso ali que tem que ser [feito.]

[Óh.] É. É isso?

Só que assim, quando eles, acho uma coisa que eles deveriam ter visto ali, porque daí caiu na mídia, pessoal, porque quando eles assinaram esse papel lá em cima, ele assinaram, de livre espontâneo... tanto ela quanto ele, que haveria conflitos... tendeu? Eles não assinaram o papel só:: que nem aqui, lá a assinatura deles quando eles entraram lá, des(de) os, dos sexos que eles fazem debaixo do edredom... até tudo eles são responsáveis pelos seus atos... eles assinaram um termo de responsabilidade... [só que::....]

[Só que::]

[Mas mesmo] lá dentro funciona::: a mesma legislação [que funciona aqui fora, né?]

[Não, eu concordo com a senhora.]

E aí é:: até o que [ficou é::.....]

[Tem que pensar nos atos também.] 
Em termos genéricos, a recontextualização implica a intercalação de um gênero secundário da esfera midiática (notícia) na composição de outro gênero secundário, da esfera assistencial (sessão de grupo socioeducativo). Esse processo envolve um tratamento do tema da notícia atravessado pelo (a serviço do) tema da sessão, de modo que este é quem determina a maneira como aquele será focalizado, havendo, portanto, via gênero discursivo, a articulação entre masculinidades regionais (figuradas no âmbito da mídia, via notícia) e masculinidades locais (figuradas no âmbito da prática do grupo, via sessão de grupo socioeducativo).

Note-se, assim, que a orientação dada pelos autores da notícia não é contemplada na leitura desta no contexto da sessão. Se, conforme é possível verificar na notícia (Conf. Anexo A), o horizonte temático são as atitudes machistas de Marcos, participante de um Reality Show, e a omissão da Rede Globo, canal que produz e veicula o programa, diante do caso; na sessão, apenas as atitudes de Marcos são focalizadas (A minha notícia é sobre o Big Brother, aquele cara - linha 1143-1144).

Esse aspecto vai orientar todos os enunciados seguintes, nos quais se discute, então, a atitude do participante do programa televisivo. Note-se que o enunciado de Edvan também não reporta a ideia de machismo, presente na crítica feita pela notícia. De fato, é justamente a categorização do que ocorreu no âmbito do programa televisivo o assunto que pautará todo o embate discursivo na sequência da sessão, mostrando o quanto a linguagem é capaz de registrar as fases mais transitórias, mais efêmeras das mudanças sociais (VOLOCHINOV, 2014, p. 42).

O modo como os participantes se colocam na discussão do fato (para além de Edvan, o único que leu a notícia inteira) demonstra que eles já estavam cientes do ocorrido (ou porque acompanham o programa em questão ou porque têm acesso aos veículos que o publicizam). Veja que os participantes apontam detalhes que não estavam na notícia (O Marcos, né, do Big Brother, ele também é médico acho esse cara, né? - Edvan_S10L1150-1151; Ele é.:: cirurgião plástico. Ivan_S10L1152; A Globo tirou ele, né, [...] Edvan_S10L1158; [A delegada que tirou.] - Ivan_S10L1159).

A partir da linha 1163, o embate acerca do que teria ocorrido no âmbito do programa é intensificado. Nesse caso Edvan explica o motivo que levara uma "delegada buscar ele [Marcos]". Em sua explicação, percebe-se a dificuldade de nomear a atitude de Marcos. Primeiramente, Edvan a nomeia de "agressão", mas logo reformula sua fala, negando que Marcos tenha agredido Emilly $(\dot{E}$, ele foi, é que::: agrediu, ele não agrediu, mas [...] - linhas 1163-1164). No entanto, Edvan tem dificuldade de encontrar uma palavra que signifique o fato. Isso é claro pela pausa e prolongamento que marcam sua fala ([...] ele... é::.... - linha 1164).

Na sequência, o sentido para a violência sofrida por Emilly passa a ser co-construído mais explicitamente entre os integrantes da sessão. Assim, eu sugiro o termo "coação", que marca um dos aspectos de violência psicológica previstos na Lei Maria da Penha ([...] controlar suas ações, comportamentos, crenças e decisões, mediante ameaça, constrangimento [...] - BRASIL, 2010, p. 14). Edvan o reenuncia em tom de concordância e acrescenta mais um termo: "diminuição" ([...] [Coagiu ela], diminuiu ela [...] - linha 1167). Álvaro, então, nos “corrige”, enfatizando que Marcos “na verdade repreendeu” (linha 1170).

Após essa última fala, a tensão que o tema suscita nos integrantes da sessão é marcada pela emergência de conversas sobrepostas (a partir da linha 1171). Tal tensão deriva em grande medida do embate entre o reconhecimento e o não reconhecimento desse tipo de violência enquanto tal. Diante disso, os participantes buscam modos de discursivizar o acontecido e detalham não só o fato, mas também aspectos das atitudes de Marcos em outros momentos do programa que sustentariam alguma coerência em sua biografia diante do episódio em discussão ([...] ((incompreensível)) pras as outras meninas também ele aprontou pra todas elas lá e... e depois ele andou::: quase que, não, só não bateu acho que porque ele sabia que tava na TV, né, mas ele::: ele segurou ela pela mão lá num canto... - Edvan_S10L1174-1178; >E meteu o dedo na cara dela.< [...] - Ivan_S10L1179; [...] e::. fazia com o dedo assim ((encena o que diz)) [...] Edvan_S10L1180).

Os horizontes axiológicos de Ivan e Edvan parecem convergir dado que ambos detalham o fato como violento e buscam tornar esse sentido coerente a partir da biografia de Marcos. Assim, embora não explicitem com o termo "violência", parecem compreender a agressão de Marcos como um tipo de violência. Isso aponta para deslocamentos importantes, especificamente para o fato de a violência (ao menos a do outro) tornar-se percebida pelos que ocupam posições de dominação de gênero social (KIMMEL, 1998). 
Além disso, o próprio Edvan reconhece mais adiante (linha 1242), que poderia ter feito o mesmo naquelas circunstâncias. Esse fato demonstra em alguma medida o reconhecimento de seu lugar a partir de um excedente de visão, de um outro contra o qual Edvan se coloca (no caso, Marcos). A "descoberta” é então uma forma de perceber a si mesmo, exotopicamente, a partir desse outro. O outro é ele mesmo.

É contra esse horizonte axiológico que Álvaro novamente se enuncia. Veja-se que ele reitera o termo "repreensão" e nega os sentidos derivantes da avaliação de Ivan e Edvan $\left({ }^{\circ} \mathrm{Na}(o) \ldots\right.$ ele repreendeu. ${ }^{\circ}$ - Álvaro_S10L1183). A postura de Álvaro contrasta com a de Edvan, na medida que encarna esse outro (Marcos) e o defende. Intersubjetivamente, Álvaro defende a si mesmo.

Álvaro se distancia de seus pares, reitera seu posicionamento, ainda que de forma modalizada, já que fala em tom baixo. No entanto, seu enunciado é retomado por Ilma, que reitera a disputa pelo significado do ato noticiado (É. É... uma repreensão é:: é uma coisa diferente [...] - Ilma_S10L1186). Essa disputa, conforme afirma Fairclough (2001; 2003), não é simplesmente por uma ou outra palavra, mas pela forma de dar acabamento a uma realidade (BAKHTIN, 2003; MEDIVIÉDEV, 2016; VOLOCHÍNOV, 2014), cujas implicações alcançam pessoas na realidade de práticas cotidianas.

Ainda, tal disputa ilustra a complexidade das relações dialógicas participantes da cadeia complexamente organizada da vida, aspecto intensificado pela estrutura composicional da sessão como gênero discursivo organizador dessa prática e pelas relações dialógicas na rede de práticas da qual a sessão participa. A disputa que se segue ao longo da sessão pode ser sistematizada assim: há modos de acabamento que i) legitimam o ato noticiado como violência; ii) encaminham-se para a compreensão deste como violência e iii) negam-no como violência e o vinculam a uma atitude de "macheza", "ajuda à mulher". Há, portanto, neste último caso, formas de conceber masculinidade e feminilidade, vinculando esta à infantilização e dependência e aquela ao domínio.

No excerto em análise, o primeiro modo de acabamento é construído por Ilma e por mim; o segundo, por Ivan e Edvan; o terceiro, por Álvaro. As diferenças entre esses horizontes são marcadas, obviamente, pela orientação temática da sessão e o cerceamento (HANKS, 2008) que a esfera de atividade exerce sobre aqueles que dela participam, bem como pelas posições dos participantes e facilitador/as no âmbito do gênero sessão de grupo socioeducativo.

Esse fato poderia explicar a aproximação de Ivan e Edvan a Ilma e seu distanciamento de Álvaro, podendo ser uma estratégia de criar uma autoidentidade positiva diante dos/as facilitador/as; mas não explica o posicionamento de Álvaro, que estaria, então, criando "estrategicamente" (?) uma autoidentidade negativa de si. Apesar disso, Álvaro explicita a pressão da esfera quando enuncia concordância com Ilma ([Sim, mas ali::] - linha 1190; É uma violência. [...] - linha 1196; Isso é uma violência. - linha 1203; [Houve.] - linha 1222), embora reitere recorrentemente seu posicionamento discordante em seguida.

O horizonte axiológico, recorte da realidade feito por Álvaro aponta, ainda, para a vinculação entre violência e masculinidade (hegemônica). Veja-se que ele explica a agressão, enunciada como "repreensão", como uma "imposição de macho" (linha 1200) para limitar as ações da mulher ([E é uma violência que não, pra repreender você,] pra você não passar dali. - linhas 1207-1208; se eu não parar verbalmente eu vou tentar te por [uma:.:.] [...] imposição de macho ali pra:: tu. - linhas 1196-1198; 1200). Nesse caso, sua explicação se pauta na naturalização da relação "ser macho-ser violento” (WELZER-LANG, 2001). Além disso, se pauta num quadro interpretativo que separa a violência verbal da física, sendo esta última entendida como uma ação "de macho", pois "macho não conversa, ele agride".

A naturalização da relação entre masculinidade e violência apareceu, em outros momentos, em discursos de outros participantes, não ocupando o foco de sua atenção discursiva. São pressupostos não problematizados e apontam o quanto a dominação masculina via violências é mesmo parte do habitus social (BOURDIEU, 2010). Nesse caso, quando Jaime narra o momento em que seu tio, vendo-o cozinhar, reprovou sua atitude, iniciando uma discussão, utiliza a expressão "chegou virando homem" para dar conta da atitude violenta ([...] Meu tio chegou virando homem "Isso é coisa de mulher." [...] Aí ele chegou e falou "Isso é coisa de mulher, pra fazer... isso não se faz e não sei quê e não sei quê.” - Jaime_S01L1515-1520). 
De modo mais explícito, essa vinculação fez-se presente também nos enunciados de outros participantes, num tom algumas vezes de justificativa para suas ações no presente, mas também de crítica e reprovação desse tipo de ação. Ivan, por exemplo, ao falar das brincadeiras de infância, aponta para o modo como os brinquedos "de meninos", objetos substancialmente relacionados à constituição de masculinidades e feminilidades (CALDAS-COULTHARD; VAN LEEUWEN, 2004), se relacionavam com brincadeiras violentas. ([...] cê tinha um carrinho ali... o carrinho tinha que bater pra quebrar o carrinho do outro... é verdade ou não é? O homem não é criado pra proximidade... [...] - Ivan_S14L395-398).

No caso de Álvaro, ainda, além dessa vinculação entre violência e masculinidade, a ideia de repreensão está atrelada à de "ajudar a mulher", "educá-la", assim como se educam os filhos, sentido atrelado ao ato de Marcos "corrigir" Emilly quanto ao uso de álcool (Conf. notícia). É visível que Álvaro assume o ponto de vista de Marcos e busca sustentar a coerência do ato deste último, a partir de um posicionamento paternalista ilustrado em outros momentos de seus enunciados, como quando ele defende que uma mulher mais jovem "cairia fácil na lábia de um homem mais velho" ([... eu sou o pai de uma menina, de vinte e um ano... co... será que eu gostaria de ver ela com um velho de trinta de quarenta ano? Porque ela também tem que analisar... eu não quero vamos dizê assim, se aproveitar da situação... porque pode ser que no momento ela teje carente... precisando de uma conversa de uma palavra... aí tu chega ali porque uma pessoa mais madura ele tem a palavra disposta na boca... queira ou não queira tem... [...] Álvaro_S10L2446-2445).

Por fim, outra implicação relacionada com o processo de recontextualização, via intercalação de gêneros, e o modo de resignificar masculinidade e violência diz respeito a mais uma explicação de Álvaro sobre a ocorrência do fato noticiado. Nesse caso, após a fala de Edvan, reconhecendo modalizadamente que também poderia agir como Marcos nas circunstâncias em que este estava, Álvaro explica que tanto Marcos quanto Emilly assinaram um contrato para participar do reality show, de modo que deveriam aceitar tudo o que ali ocorresse (linhas 1245-1254).

Essa explicação diz respeito ao tema da notícia recontextualizado dentro da sessão e, portanto, lança respostas tanto à notícia quanto à sessão. No primeiro caso, constrói-se o sentido de que a Rede Globo não deveria ser criticada pelas ações que ocorreram no reality show, já que estas eram de responsabilidade dos participantes via assinatura de contrato. No segundo caso, de que a assinatura de um contrato (metáfora para o contrato de casamento) pressupõe a liberdade irrestrita na relação, inclusive a de agressão, tendo os cônjuges - centralmente a mulher - que suportá-la sem a interferência de alguém de fora (metaforizada pela expressão "porque daí caiu na mídia, pessoal”, em que Álvaro aponta essa interferência como o problema da situação). Essa metáfora do casamento é uma resposta ao horizonte temático da sessão, segundo o qual, uma interferência de fora (o que a própria política pública do grupo significa) seria necessária, legítima.

Há ainda a legitimação do discurso segundo o qual o contrato de casamento divide a vida entre privado e público, sendo que entre tais ambientes não haveria mútua interferência, bem aos moldes das relações burguesas emergentes na modernidade, conforme Giddens (1993).

Em resumo, a recontextualização via intercalação de gêneros implica (re)acentuação de aspectos da dimensão temática do gênero reportado (notícia) a serviço do tema do gênero aglutinador (sessão). Assim, há leituras e respostas preferenciais. No caso da notícia recontextualizada na sessão de grupo, houve o apagamento de aspectos da esfera midiática (a crítica à empresa de mídia concorrente) e a acentuação do fato noticiado (a violência contra mulher cometida por um homem no âmbito de um programa televisivo).

Tal fato, porém, foi significado à luz da heterogeneidade axiológica que marca o contexto da sessão de grupo, figurada na relação “violência X não-violência/repreensão". Nesse caso, indiretamente age-se sobre o tema da própria notícia, que enquadrara o fato a partir de um determinado horizonte axiológico. Assim, os sentidos que a notícia buscou fechar (machismo/violência) foram discutidos justamente nos pontos que tornavam o significado aberto, ou seja, agiu-se sobre a potencialidade semiótica e sua articulação com a realidade (o fato noticiado), algo possibilitado pelos aspectos que constituem a sessão como gênero discursivo, sobretudo seu horizonte temático e sua estrutura estilístico-composicional. 
Nesse sentido, a sessão aparece aqui como lócus que possibilita encontro entre diferentes horizontes axiológicos e, consequentemente, emergência de modos diversos de significar a realidade, modos de inscrever na história e na linguagem masculinidades outras, para o que o reconhecimento de si, por exemplo, a partir de um outro (caso de Edvan), é significativo. Esse aspecto de alteridade se mostrou relevante em outras circunstâncias do grupo, sobretudo pela busca de compreender a realidade a partir do ponto de vista da mulher, vista, então, não como objeto, mas como um sujeito com motivos, vontades e independência. No excerto abaixo, por exemplo, numa conversa na recepção, Vicente responde a Arthur, que questiona a imputação da medida protetiva pedida pela ex-mulher. Veja que Vicente se coloca no lugar da mulher a fim de levar Arthur a ler a situação de um modo diferente.

\section{(14)}

\begin{tabular}{|c|c|}
\hline 383 & Vanessa \\
\hline 384 & \\
\hline 385 & Arthur \\
\hline 386 & Vanessa \\
\hline 387 & Arthur \\
\hline 388 & Vanessa \\
\hline 389 & Arthur \\
\hline 390 & \\
\hline 391 & \\
\hline 392 & \\
\hline 393 & \\
\hline 394 & \\
\hline 395 & Vanessa \\
\hline 396 & \\
\hline 397 & \\
\hline 398 & \\
\hline 399 & Arthur \\
\hline 400 & \\
\hline 401 & \\
\hline 402 & \\
\hline 403 & \\
\hline 404 & Vicente \\
\hline 405 & Arthur \\
\hline 406 & Vicente \\
\hline 407 & \\
\hline 408 & Arthur \\
\hline 409 & Vanessa \\
\hline 410 & Vicente \\
\hline 411 & \\
\hline 412 & Vanessa \\
\hline 413 & \\
\hline 414 & Vicente \\
\hline 415 & \\
\hline 416 & \\
\hline 417 & Arthur \\
\hline 418 & Vicente \\
\hline 419 & \\
\hline 420 & \\
\hline 421 & \\
\hline 422 & \\
\hline
\end{tabular}

Mas teve... mas deve ter tido alguma motivação pra pedir a medida, será que nenhuma? [No momento...] [não não:::]

Que as vezes no momento acontece alguma coisa... [a discussão de bo...] [depois passa e:::]

discussão de boca. mas jamais nunca... a mãe das minhas filha, jamais ia... ter coragem de fazer alguma coisa contra ela. Aí eu faço alguma coisa contra ela, ela vai pro cemitério eu vou pra cadeia e as minhas filhas? É duas pequena, né? [e eu penso nisso. ]

[É que as histórias assim] hoje em dia são tão:: comum essas de acontecer isso assim, né, então::: por medida de segurança a justiça acaba colocando [esse tipo de:::]

[Não mas não tem nada a ver...] como é que ela vai?... Comoé que eu vou ver as meninas com essa medida protetiva? Como é que eu vou chegar perto d::: Então ela já fez isso já com caso pensado, entendeu?

Você já não tá causando:: medo nela?

Nã::o, [medo de quê?]

[Não... Sab...] Sabe que o próprio:: medo:: [ajuda fazer isso, né?]

[Não não::]

Uhum:::

O próprio medo... Não é que, [o senhor tem culpa, entendesse? Não é que o senhor tem culpa...]

[Às vezes os próprios filhos falam às vezes também cê fala alguma coisa...]

Não tô definindo sua pessoa, que o senhor tem culpa, só que eu tô falando o lado dela, entendeu? De tanta de tanta [discur...] [nã::]

de tanta discussão que teve, talvez nesse momento ela... tirou um::: um momento que ela decidiu "vou pegar uma medida protetiva porque ele::: tá:: ele pode fazer alguma coisa pra mim" [((incompreensível))]

(Vários_recepçãoS07L383-422)

No excerto acima, Arthur afirma que a mulher solicitara a medida protetiva como forma de afastá-lo das filhas (linha 402-403). Ele não significa a discussão que teve com a ex-mulher como violência. Então, Vicente se coloca no lugar da mulher ([...] só que eu tô falando o lado dela, entendeu? - linhas 415), de modo a tentar fazer Arthur compreender que possa ele ter provocado medo na mulher. Veja-se que Vicente coloca Arthur como motivador do que gerou a medida (Você já não tá causando:: medo nela? - linha 
404). Ele aloca, então, os sujeitos da situação de violência em posições diferentes das narrativas comuns daqueles que chegam ao grupo (de vitimização própria, de culpabilização da mulher, de negação da violência).

Vicente legitima também a imputação judicial e, consequentemente, busca mostrar, embora não tenha informações claras do caso, a validade do pedido da ex-mulher de Arthur, sua ação enquanto sujeito de direito. Vicente usa, inclusive, o discurso direto, retomando a voz da mulher (linhas 419-421), trazendo-a para a discussão e ilustrando os efeitos da sessão de grupo socioeducativo na rede de práticas sociais nas quais os homens que por ali passa(ra)m se engajam.

\section{CONCLUSÃO}

A sessão de grupo socioeducativo se relaciona com as práticas (re)reconstrução de masculinidades na medida em que tematiza justamente a necessidade de mudanças nas relações pautadas na violência de homens sobre mulheres e sobre outros homens que não atendam ao padrão hegemônico. A estruturação estilístico-composicional do gênero discursivo sob escrutínio, um texto-ritual, possibilita a emergência de disputas sobre os modos de acabamento da realidade social, especialmente pelo fato de centrar-se na conversa entre sujeitos com distintos horizontes axiológicos. Nesse sentido, masculinidades hegemônicas são problematizadas em prol da emergência de formas outras de constituir-se. Assim, a violência contra a mulher é trazida ao discurso a fim de ser desnaturalizada e separada das formas valoradas de masculinidade.

Por fim, o modo de funcionamento da sessão, no momento da atividade de grupo, torna inteligível a complexa relação entre linguagem e prática social, especialmente em termos de (re)acentuação de aspectos da dimensão temática de gêneros reportados (notícia) a serviço do tema do gênero aglutinador (sessão). Tal processo implica apagamento de aspectos de uma esfera, midiática no caso analisado (a crítica à empresa de mídia concorrente), e a acentuação do fato noticiado (a violência contra mulher cometida por um homem no âmbito de um programa televisivo), mostrando o caráter aberto da constituição da realidade social e o modo como a disputa por determinados aspectos dos gêneros discursivos (horizonte temático, modos de estruturação) é a disputa sobre as formas de constituição da realidade.

Longe de estar restrito à sessão, esse aspecto é constitutivo dos gêneros como instância realizadora das práticas, o que pode lançar subsídios teóricos para que se (re)pense os modos de tensionamento das práticas nas diferentes esferas de atividades e na constituição da realidade social, das autoidentidades.

\section{REFERÊNCIAS}

BAKHTIN, M. O problema do conteúdo, do material e da forma na criação literária. In: BAKHTIN, M. Questões de literatura e estética: a teoria do Romance. São Paulo: Hucitec, 1988[1975]. p. 13-70.

BAKHTIN, M. Os gêneros do discurso. In: BAKHTIN, M. Estética da criação verbal. 4. ed. São Paulo: Martins Fontes, 2003 [1952/53].p. 261-306.

BARWASHI, A. S.; REIFF, M. J. Gênero: história, teoria e pesquisa. São Paulo: Parábola, 2013

BAZERMAN, C. Gêneros textuais, tipificações e Interação. São Paulo: Cortez, 2009

BONINI, A. Análise crítica de gêneros discursivos no contexto das práticas jornalísticas. In: SEIXAS, L.; PINHEIRO, N. F. (org.). Gêneros: um diálogo entre Comunicação e Linguística Aplicada. Florianópolis: Insular, 2013. p. 103-120.

BONINI, A. Gênero textual/discursivo: o conceito e o fenômeno. In: CRISTOVÃO, V. L. L.; NASCIMENTO, E. L. (org.). Gêneros textuais: teoria e prática. Londrina, PR: Moriá, 2004. p. 3-17. 
BONINI, A O jornal escolar como mídia contra-hegemônica: jornalismo de escola não modelado pelo jornalismo comercial dominante. Linguagem em (Dis)curso (impresso), Tubarão, v. 17, p. 165-182, 2017.

BONINI, A. et al. Os gêneros do jornal. Florianópolis: Insular, 2014.

BOURDIEU, P. A dominação masculina. Rio de Janeiro: Bertrand Brasil, 2010.

BOURDIEU, P. Esboço de uma teoria da prática. In: BOURDIEU, P. Sociologia. São Paulo: Ática, 1994. p. 46-81.

BRASIL. [Lei Maria da Penha (2006)]. Lei Maria da Penha: Lei no 11.340, de 7 de agosto de 2006, que dispõe sobre mecanismos para coibir a violência doméstica e familiar contra a mulher. - Brasília : Câmara dos Deputados, Edições Câmara, 2010.

CALDAS-COULTHARD, C. R.; VAN LEEUWEN, T. Discurso crítico e gênero no mundo infantil: brinquedos e a representação de atores sociais. In: Linguagem em (Dis)curso, Tubarão, v. 4, n.esp, p. 11-33, 2004.

CHOULIARAKI, L.; FAIRCLOUGH, N. Discourse in late modernity: rethinking critical discourse analysis. Edinburgh: Edinburgh University Press, 1999.

CONNELL, R. W. Masculinidades. México: Univerdidad Nacional Autónoma de México, 2003

CONNELL, R. W.; MESSERSCHIMIDT, J. W. Masculinidade hegemônica: repensando o conceito Revista de Estudos Feministas, Florianópolis, v.21, n.1, p. 441-282, jan./abr. 2013.

FAIRCLOUGH, N. Analysing discourse: textual analysis for social research.London: Routledge, 2003.

FAIRCLOUGH, N. Discurso e mudança social. Brasília: EditoraUnB, 2001[1992].

GIDDENS, A. A transformação da intimidade: sexualidade, amor e erotismo nas sociedades modernas. São Paulo: Editora da Universidade Estadual Paulista, 1993.

GIDDENS, A. As consequências da modernidade. São Paulo: Editora Unesp, 1991.

GIDDENS, A. Modernidade e identidade. Rio de Janeiro: Jorge Zahar Ed., 2002.

HANKS. W. Língua como prática social: das relações entre língua, cultura e sociedade a partir de Bourdieu e Bakhtin. São Paulo: Cortez, 2008.

KIMMELL, M. A produção simultânea de masculinidades hegemônicas e subalternas. Horizontes Antropológicos, Porto Alegre, ano 4, n. 9, p. 103-117, out. 1998.

LEITE; F. LOPES, P. V. L. Serviços de educação e responsabilização para homens autores de violência contra mulheres: as possibilidades de intervenção em uma perspectiva institucional de gênero. In: LOPES, P.V. L.; LEITE, F. Atendimento a homens autores de violência doméstica: desafios à política pública. Rio de Janeiro: Iser, 2013. p. 17-44.

MASON, J. Qualitative Researching. London: SAGE Publications, 1998. 
MEURER, J. L.; MOTTA-ROTH, D. Introdução. In: MEURER, J. L; MOTTA-ROTH, D. Bauru. (org.). Gêneros textuais e práticas discursivas: subsídios para o ensino da linguagem. Bauru: EDUSC, 2002. p. 09-14.

MIEDVIÉDEV, P. N. Os elementos da construção artística. In: MIEDVIÉDEV, P. N. O método formal nos estudos literários: introdução a uma poética sociológica. São Paulo: Contexto, 2016 [1928]. p. 193-207.

MOITA-LOPES, L. P. (org.). Por uma linguística aplicada indisciplinar. São Paulo: Parábola, 2006.

MOTTA-ROTH, D. Análise crítica de gêneros com foco em notícias de popularização da ciência. In: SEIXAS, L.; PINHEIRO, N. F. (org..). Gêneros: um diálogo entre Comunicação e Linguística Aplicada. Florianópolis: Insular, 2013. p. 121-145

MOTTA-ROTH, D.; MARCUZZO, P. Ciência na mídia: análise crítia de gênero de notícias de popularização cintífica. In: Revista Brasileira de Linguística Aplicada, v.10. n. 3, p. 511-538, 2010

NOLASCO, S. A. O trabalho como base para a identidade. In: O mito da masculinidade. Rio de Janeiro: Rocco, 1993. p. 50-72

RODRIGUES, R. H. Análise de gênero do discurso na teoria bakhtiniana: algumas questões teóricas e metodológicas. In: Linguagem em (Dis)curso, Tubarão, v. 4, n. 2, p. 415-440, jan./jun. 2004.

SCOTT, J. Gender: a useful category of historical analyses. Gender and the politics of history.NewYork, Columbia University Press, 1989. Versão em português: Gênero: uma categoria útil para a análise histórica. Tradução de Maria Betânica Ávila. 2005. Disponível em: http://disciplinas.stoa.usp.br/pluginfile.php/185058/mod_resource/content/2/G\%C3\%AAnero-Joan\%20Scott.pdf. Acesso em: 20 fev. 2016.

VOLOCHÍNOV, V. N. Marxismo e Filosofia da Linguagem: problemas fundamentais do método sociológico da linguagem 16. ed. São Paulo: Hucitec, 2014 [1929].

WELZER-LANG, D. Les hommes violents. Paris: Payot, 1991.

\section{() $\circledast \circledast$}

Recebido em 28/11/2019. Aceito em 07/01/2020. 
ANEXO A - Notícia “Globo não consegue combater machismo explícito de Marcos dentro do BBB”. Fonte: material apresentado em Soares (2018).

\section{Globo não consegue combater machismo explícito de Marcos dentro do BBB}

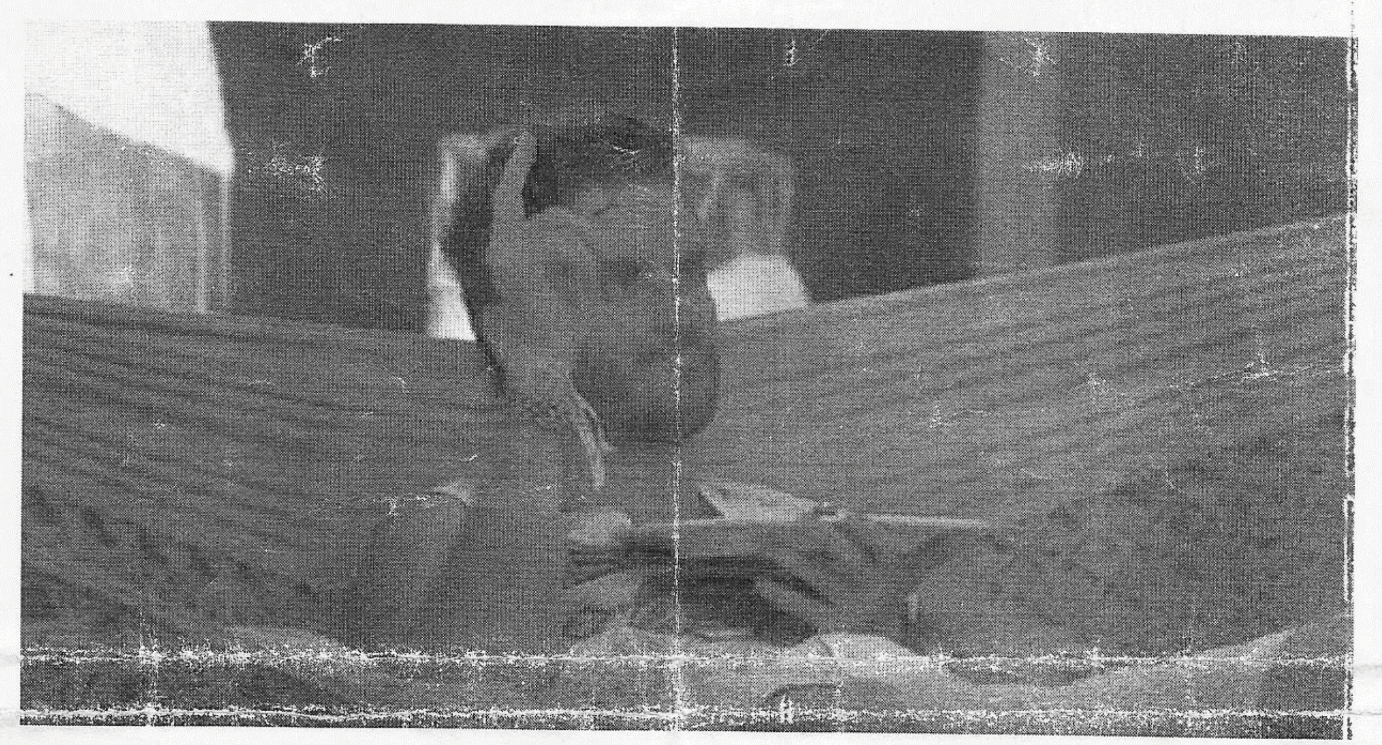

Marcos durante a festa desta noite no BBB (Foto: Reprodução/Globo)

Já rolaram algumas provas do machismo latente de Marcos, basta lembrar o "surto" que o fez sair gritando e apontando o dedo para todas as mulheres da casa. E nesta noite de quarta para quinta rolou mais um de seus absurdos. Marcos soltou a seguinte pérola: "evita pegar a garrafa, que é muito feio mulher segurando garrafa. Uma das cenas mais feias que eu vi na vida foi uma noiva se servinilo com um copo de cerveja". Emilly retrucou: "mas se não tem homem pra servir, a gente tem que se servir". Marcos encerrou a conversa: "calma, isso é secundário. Vamos curtir a festa".

Deve ser complicado para a Globo alguém como Marcos dentro do BBB. Do lado de fora, o canal tem de lidar com o caso de José Mayer e com a fala machista de Otaviano Costa no Vídeo Show (ele se desculpou no ar). O canal sempre reforça de que não apoia este tipo de atitude e daí vem o Marcos dentro de um programa da casa soltando todo o tipo de machismo e sexismo. Só que nesse caso, a Globo nem pode fazer nada a respeito, a não ser que haja agressão.

Difícil, né? De um lado coíbe o machismo, mas de outro tem um programa que fica propagando isso fortemente. 